\title{
Trans-septal suturing technique in septoplasty: a systematic review and meta-analysis*
}

\author{
Victor Certal', Helder Silva², Tiago Santos², Alexandra Correia², \\ Carlos Carvalho² \\ Department of Otorhinolaryngology, Hospital Sao Sebastiao, Sta Maria da Feira, Portugal, CINTESIS - Center for Research in \\ Health Technologies and Information Systems, University of Porto, Porto, Portugal \\ Department of Otorhinolaryngology, Hospital Sao Sebastiao, Sta Maria da Feira, Portugal
}

Rhinology 50: 236-245, 2012 DOI:10.4193/Rhino12.051

*Received for publication:

March 26, 2012

Accepted: April 19, 2012

\section{Summary}

Statement of problem: Trans-septal suturing techniques are routinely used to obviate the need for packing after septoplasty surgery. This study aimed to systematically assess the evidence for the efficacy and safety of suturing techniques after septoplasty.

Methods: A MEDLINE, Scopus, Cochrane Library, and ProQuest Dissertations \& Thesis Database search, followed by extensive hand-searching for the identification of relevant studies. No time and language limitations were applied. Only prospective randomized controlled trials (RCTs) comparing trans-septal suturing techniques following septoplasty with conventional packing were included. For each outcome, risk difference and 95\% confidence intervals (Cls) were calculated. Tests for heterogeneity and tests for publication bias were applied.

Results: Eight RCTs with 869 patients were included in the review. Postoperative pain and headache were significantly lower in the non-packing group. Conventional packing and trans-septal suturing technique appear to be equivalent with regard to postoperative haemorrhage risk, mucosal adhesions, septal perforation, septal haematoma and local infection.

Conclusions: The evidence for the advantage of suturing techniques over conventional packing in septoplasty is now robust, and the use of suturing techniques as a first line intervention is becoming advisable.

Key words: septoplasty, nasal packing, trans-septal suturing technique, systematic review, meta-analysis

\section{Introduction}

Septoplasty -one of the most common operations performed in otolaryngology- has continually evolved from ancient times, and nasal packing has been considered to be a fundamental step of the surgery in different techniques ${ }^{(1)}$.

The use of postoperative packing has been proposed to minimize postoperative complications such as haemorrhage, mucosal adhesions, and septal haematoma. Additionally, postoperative packing is believed to stabilize the remaining cartilaginous septum and minimize the persistence or recurrence of septal deviation.

Despite these theoretical advantages, evidence to support the use of postoperative packing is lacking. Moreover, nasal packing is not an innocuous procedure. The most common morbidity associated with packing is postoperative pain ${ }^{(2-4)}$. Additional potential complications include the worsening of sleep-disordered breathing and postoperative infection, including toxic shock syndrome resulting from postseptoplasty packing ${ }^{(5)}$. Therefore, the use of nasal packing is associated with several risks that should question the routine application of this procedure, given the lack of firm evidence to support its efficacy ${ }^{(1)}$. Intranasal (septal) splints have been used as an alternative to nasal packing to prevent intranasal adhesions and maintain septal stability, but similar to nasal packing, septal 
splints have indicated morbidity ${ }^{(1)}$.

To overcome these issues, many surgeons use suturing techniques to obviate the need for packing after surgery ${ }^{(6)}$. Several suturing techniques have been described to approximate the mucosal flaps after septal procedures to reduce the complication rate ${ }^{(7)}$. In 1984, Sessions et al., ${ }^{(6)}$ reported continuous suture quilting using 4.0 plain catgut on a small cutting needle to approximate the mucosal flaps. A similar technique using a curved needle was described by Lee et al. ${ }^{(7)}$. These techniques also help to close mucosal tears and support the remaining cartilage $^{(8)}$

Although current world literature indicates that packing should be avoided, to our knowledge, no meta-analysis study has been conducted to support this recommendation. Therefore, the present study aimed to systematically review the evidence to answer key clinical questions on the efficacy and safety of trans-septal suturing techniques after septoplasty.

\section{Methods}

\section{Study design}

A systematic review and meta-analysis of randomized controlled trials (RCTs) focusing on the efficacy and safety of suturing techniques following septoplasty was undertaken. The methodological approach included the definition of search strategies, quality assessment of the studies, data abstraction, and statistical data analysis ${ }^{(9)}$.

\section{Search strategy}

Our primary method to locate potentially eligible studies involved a computerized literature search of the MEDLINE database from inception to January 2012 -without any restriction on the language of publication- using the following search keywords and MeSH terms: (septoplasty, nasal surgery, or septal surgery); (packing, suture technique, or quilting technique); and (clinical and trial, clinical trials, clinical trial, random*, or random allocation). Literature searches were also undertaken using the same search keywords in the following databases: the Cochrane collaboration, SCOPUS, and ProQuest Dissertations \& Thesis Database.

While defining all search strategies, we assigned priority to formats with higher sensitivity to increase the probability of identifying all relevant articles.

We also reviewed the references of all relevant articles and review articles, hand-searched abstracts, and conference proceedings of recent relevant congresses and scientific forums from 2005 to 2011, and contacted experts working in this field.

\section{Study quality assessment and data abstraction}

In the first phase of selection, the titles and abstracts of the retrieved studies were screened for relevance by 2 reviewers. In the second phase, 2 reviewers (VC and HS) independently analysed the full text of articles that were identified as potentially relevant. All disagreements were settled by consensus. Data abstraction for quality assessment and pooled analysis were performed independently using a previously specified standardized form. The quality assessment considered 2 types of study quality criteria: general and specific. The general quality criteria included methodological and reporting characteristics of RCTs generally accepted as appropriate to evaluate this type of study. The specific quality criteria included characteristics specifically relevant to RCTs studying the efficacy and safety of suturing techniques following septoplasty. The primary outcome measures included patient-reported pain and postoperative haemorrhage. The secondary outcome measures included all other complications described in the included studies, with supporting evidence from at least 3 studies.

\section{Statistical analysis}

For the pooled assessment of results, we used the Der-Simonian and Laird method for the estimation of random effects. We used the risk difference (absolute risk reduction) as the scale to measure efficacy and side effects because clinicians find it to be a more intuitive and interpretable metric, as it measures the absolute difference between outcome risks in both groups, rather than odds ratios or relative risks, which many clinicians and patients find to be difficult to understand $(10,11)$. The heterogeneity of the treatment effects was assessed by the graphical inspection of forest plots and the formal use of the $Q$ statistic ( $p \leq 0.1$ ) and 12 statistic to estimate inconsistency among the study results. Potential publication bias was assessed by a visual analysis of the funnel plots, which permits the evaluation of publication bias by presenting the study's risk difference plotted as a function of its standard error, and then formally checked by the rank correlation test of Begg ${ }^{(12)}$. The data processing and statistical analysis were performed using the Cochrane Collaboration's Review Manager Software version 4.2 and RevMan Analyses software version 1.0.

\section{Results}

Search and study selection

All database searches were performed in January 2012. A flow chart of the process involved in study identification and inclusion/exclusion is shown in Figure 1.

In total, 194 articles were identified using the search strategy and sources listed. After the titles and abstracts were screened for relevance, 174 articles were excluded (the reasons for exclusion are presented in Figure 1). The remaining 20 articles were retrieved for a more detailed full-text evaluation, and 13 were excluded for the following reasons: 10 studies ${ }^{(2,13-21)}$ analysed different interventions or different outcomes, and 3 studies were not randomized trials ${ }^{(22-24)}$. One study ${ }^{(25)}$ was included after a hand search of the references of the included studies. A 


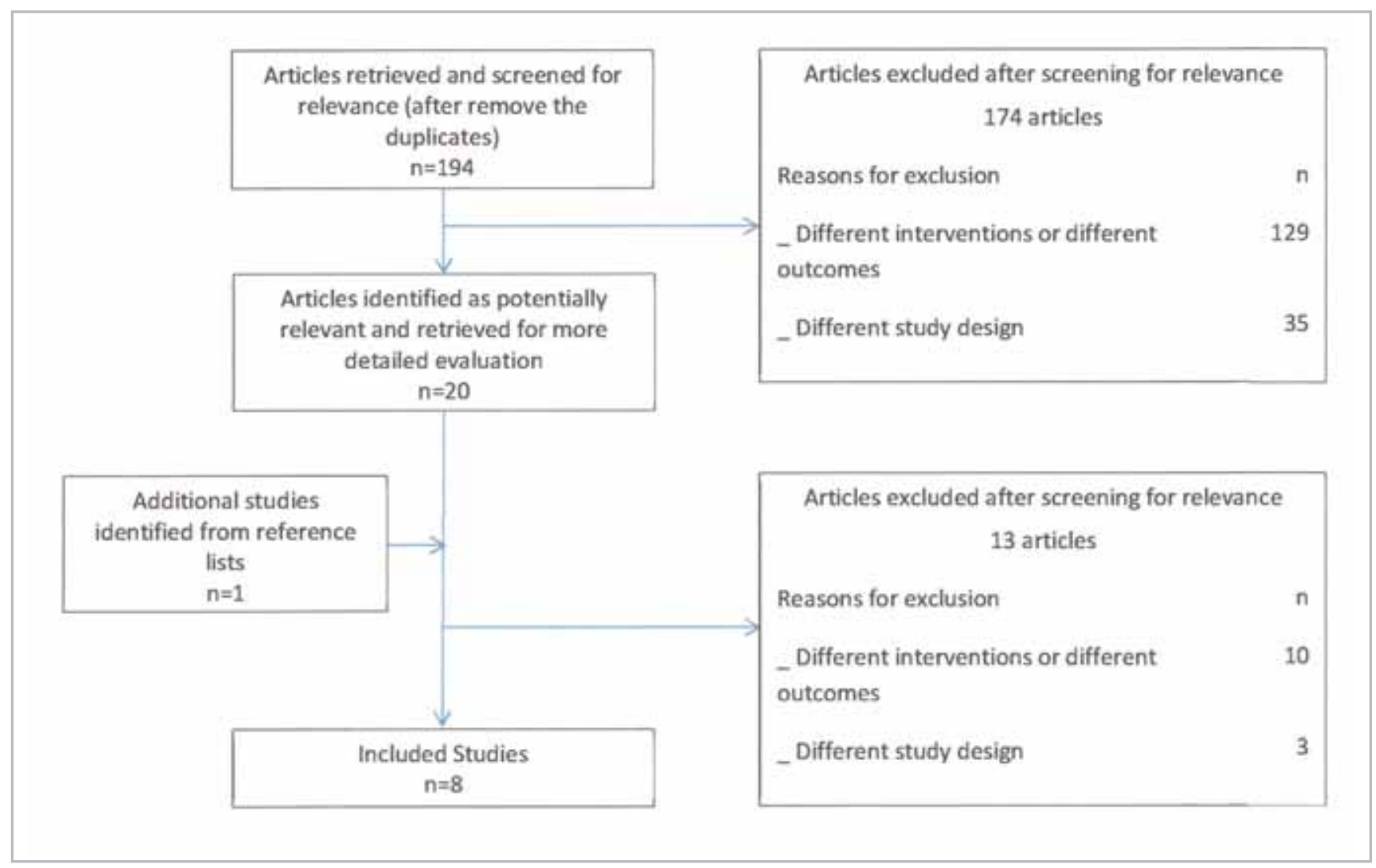

Figure 1. Flow diagram of study identification and selection.

final selection of 8 studies was included in the review ${ }^{(3,25-32)}$.

Methodological quality of included studies

The study quality assessment considered 2 types of criteria: general and specific. The general quality criteria are presented in Table 1. The studies had generally small sample sizes (mean, 108 patients; range, 48 - 200 patients); the total number of patients included was 869 . All of the included studies were of generally low quality, and most of them did not provide sufficient detail on the randomization concealment and did not correctly specify the selection criteria. Three ${ }^{(3,26,30)}$ out of 8 studies did not report an intention-to-treat analysis. None of the studies reported or commented on blinding strategies. Most of the studies reported on strategies for standardization of co-interventions and had complete follow-up details for all participants. None of the studies included sufficient detail on the objective criteria for outcome definition. The specific quality criteria are presented in Table 2 . All operations were performed under general anesthesia, and the septoplasty was performed by a standard hemitransfixation incision with little variation across the included studies. One study ${ }^{(28)}$ included septoplasty by an external approach to perform a concomitant rhinoplasty. The inclusion and exclusion criteria had some variability, with some studies including many selected groups of patients and others including a wider range of patients.
Some differences were also found among the studies regarding the packing material: 4 studies used gauze impregnated by antibiotics or Vaseline ${ }^{(3,26,28,31)}, 1$ study used Merocel ${ }^{\circledR}(25), 1$ study used a preformed Netcell ${ }^{\circledR}$ tampon ${ }^{\left({ }^{(2)}\right)}$, and 1 study used a silicon septal splint pack ${ }^{(31)}$. Only 1 study did not provide sufficient detail on the type of packing ${ }^{(30)}$. Some variations were also found among the suturing techniques, depending on the amount of cartilage removed in each case, but most of the included studies used a horizontal trans-septal suture technique to approximate the subperichondrial flaps at the end of surgery. The follow-up period varied between 7 days and 32 months, and most of studies evaluated pain between 24 to 48 hours after surgery.

\section{Primary outcome measures}

Pain

All the included trials evaluated postoperative pain/discomfort after septoplasty. However, there was a substantial variation in the outcome definition among the studies included (Table 3). We therefore did not report the pooled result. Although there was substantial heterogeneity in the criteria for pain, all the included studies reported less pain/discomfort in the nonpacking group. 


\section{Postoperative hemorrhage}

\begin{tabular}{|c|c|c|c|c|c|c|c|c|c|}
\hline \multirow[b]{2}{*}{ Study or Subgroup } & \multicolumn{2}{|c|}{ Non-Packing } & \multicolumn{2}{|c|}{ Packing } & \multirow[b]{2}{*}{ Weight } & \multirow{2}{*}{$\begin{array}{c}\text { Risk Difference } \\
\text { M-H, Random, } 954 \mathrm{CI}\end{array}$} & \multirow{2}{*}{\multicolumn{2}{|c|}{$\begin{array}{c}\text { Risk Differ ence } \\
\text { M.H, Random, } 95 \% \mathrm{Cl}\end{array}$}} & \\
\hline & Evenits & Total & Events & Total & & & & & \\
\hline Ardehall 2009 & 0 & 48 & 0 & 57 & $29.8 \%$ & $0.00[-0.04,0.04]$ & 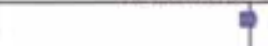 & & \\
\hline Awan 2008 & 0 & 44 & 3 & 44 & $8.0 \%$ & $-0.07[-0.15,0.02\}$ & & & \\
\hline Gunaydin 2011 & 2 & 100 & 0 & 100 & $33.8 \%$ & $0.02[-0.01,0.05]$ & e & & \\
\hline Naghibzadeh 2010 & 1 & 68 & 1 & 77 & $28.4 \%$ & $0.00[-0.04,0.04]$ & 4 & & \\
\hline Total $(95 \% \mathrm{Cl})$ & & 260 & & 278 & $100.0 \%$ & $0.00[-0.02,0.03]$ & & & \\
\hline Total events & 3 & & 4 & & & & & & \\
\hline Heterogeneity. Tau ${ }^{2}=$ & $0.00, \mathrm{Ch}$ & $=4.27$. & $d f=3(P$ & $=0.23)$ & $P^{2}=30 \%$ & & $\stackrel{5}{-1}$ & 05 & 1 \\
\hline Test for overall effect & $Z=0.14$ & $=0.89$ & & & & & Non-Packing Group & Packing Group & \\
\hline
\end{tabular}

Figure 2. Results and pooled analysis of absolute risks differences for the primary outcome postoperative haemorrhage. $\mathrm{Cl}=\mathrm{Confidence} \mathrm{Interval}$

\section{Postoperative haemorrhage}

Four trials ${ }^{(3,25,27,28)}$ contained data regarding major postoperative haemorrhage for the non-packing and conventional packing groups (Figure 2). The pooled analysis of random effects showed a statistically non-significant $1 \%$ risk reduction in postoperative haemorrhage for the packing group (95\% $\mathrm{Cl},-1 \%$ to $4 \% ; \mathrm{p}=0.28)$. Non-significant heterogeneity was found in the pooled analysis of postoperative haemorrhage (Cochran's $Q$ chi-square test, $\mathrm{p}=0.35 ; \mathrm{I} 2=10 \%$ ), and all studies but one showed risk reduction for the packing group.

\section{Secondary outcome measures}

\section{Headache}

Three trials ${ }^{(27,30,32)}$ contained data regarding postoperative headache for the non-packing and conventional packing groups (Figure 3). The pooled analysis of random effects showed a statistically significant $57 \%$ risk reduction in postoperative headache for the non-packing group ( $95 \% \mathrm{Cl}$ - $72 \%$ to $43 \% ; p<0.01$ ). Borderline significant heterogeneity was found in the pooled analysis of postoperative haemorrhage (Cochran's Q chi-square test, $p=0.09 ; 12=59 \%$ ), and all studies showed risk reduction for the non-packing group.

\section{Septal haematoma}

Four trials ${ }^{(25-28)}$ contained data regarding postoperative septal haematoma for the non-packing and conventional packing groups (Figure 3). The pooled analysis of random effects showed a statistically non-significant $0 \%$ risk reduction in postoperative septal haematoma $(95 \% \mathrm{Cl},-2 \%$ to $3 \% ; \mathrm{p}=$ 0.89). Non-significant heterogeneity was found in the pooled analysis (Cochran's $\mathrm{Q}$ chi-square test, $\mathrm{p}=0.23 ; 12=30 \%$ ).

\section{Adhesions}

Five trials ${ }^{(3,26-28,31)}$ contained data regarding the postoperative adhesions of the mucosa for the non-packing and conventional packing groups (Figure 3). The pooled analysis of random effects showed a statistically non-significant 3\% risk reduction in the postoperative adhesions for non-packing group (95\% $\mathrm{Cl},-10 \%$ to $3 \% ; \mathrm{p}=0.3$ ). Significant heterogeneity was found in the pooled analysis (Cochran's $Q$ chi-square test, $p=0.02 ; 12$ $=65 \%$ ), and all studies but one showed risk reduction for the non-packing group.

\section{Local infection}

Four trials ${ }^{(25-27,31)}$ contained data regarding postoperative local infection for both non-packing and conventional packing group. The random effects pooled analysis showed a statistically non-significant $4 \%$ risk reduction in postoperative local infection for non-packing group $(95 \% \mathrm{Cl},-10 \%$ to $3 \% ; \mathrm{p}=0.27)$. Significant heterogeneity was found in the pooled analysis (Cochran's $\mathrm{Q}$ chi-square test, $\mathrm{p}<0.01 ; 12=83 \%$ ), but all studies showed risk reduction for the non-packing group.

\section{Septal perforation}

Five trials ${ }^{(25,26,28,30,31)}$ contained data regarding postoperative septal perforation for the non-packing and conventional packing groups (Figure 3). The pooled analysis of random effects showed a statistically non-significant $1 \%$ risk reduction in postoperative septal perforation for the non-packing group $(95 \% \mathrm{Cl},-3 \%$ to $1 \% ; \mathrm{p}=0.36)$. Non-significant heterogeneity was found in the pooled analysis (Cochran's Q chi-square test, $p=0.99 ; 12=0 \%)$.

\section{Publication bias}

Funnel plots are presented in Figure 4. Although separate analyses for all outcomes and comparisons were performed, we only present here the analysis of potential publication bias for the postoperative haemorrhage because the results for other outcomes are very similar. For the postoperative haemorrhage outcome, the funnel plot is approximately asymmetrical, which indicates a lack of small studies with effects favoring the packing group. The rank correlation test of Begg gives a 


\section{a) Headache}

\begin{tabular}{|c|c|c|c|c|c|c|c|c|}
\hline \multirow{2}{*}{ Study or Subgroup } & \multicolumn{2}{|c|}{ Non-Packing } & \multicolumn{2}{|c|}{ Packing } & \multirow{2}{*}{ Weigint } & \multirow{2}{*}{$\begin{array}{c}\text { Risk Difference } \\
\text { M-H, Random, 95: } \mathrm{Cl}\end{array}$} & \multirow{2}{*}{\multicolumn{2}{|c|}{$\begin{array}{c}\text { Risk Difference } \\
\text { M.H, Random, 95\% Cl }\end{array}$}} \\
\hline & Events & Total & Events & Total & & & & \\
\hline Awan 2008 & 9 & 44 & 40 & 44 & $36.5 \%$ & $-0.70+0.85,+0.56]$ & $-\pi$ & \\
\hline Korkut 2009 & 11 & 37 & 20 & 27 & $248 \%$ & $-0.44 ; 0.66,-0.22\}$ & 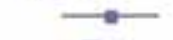 & \\
\hline Walikat 2011 & 19 & 74 & 61 & 77 & $38.7 \%$ & $=0.54+0.67,-0.40]$ & $\rightarrow-$ & \\
\hline Total $(95 \mathrm{t}$ CI) & & 155 & & 148 & 100.096 & $-0.57[-0.72,-0.43]$ & & \\
\hline Total events & 39 & & 121 & & & & & \\
\hline $\begin{array}{l}\text { Heterogeneity Tauª } \\
\text { Test for overall effect }\end{array}$ & $\begin{array}{l}0.01 ; \text { Chr } \\
Z=7.700\end{array}$ & $\begin{array}{r}482 \\
<0.00\end{array}$ & $\begin{array}{l}d f=2(P \\
001)\end{array}$ & $=0.09)$ & $\mathrm{F}^{2}=59 \%$ & & ${ }_{n-P a c k i n g}^{-0.5}$ & ${ }^{0}$ Packing Group \\
\hline
\end{tabular}

\section{b) Septal hematoma}

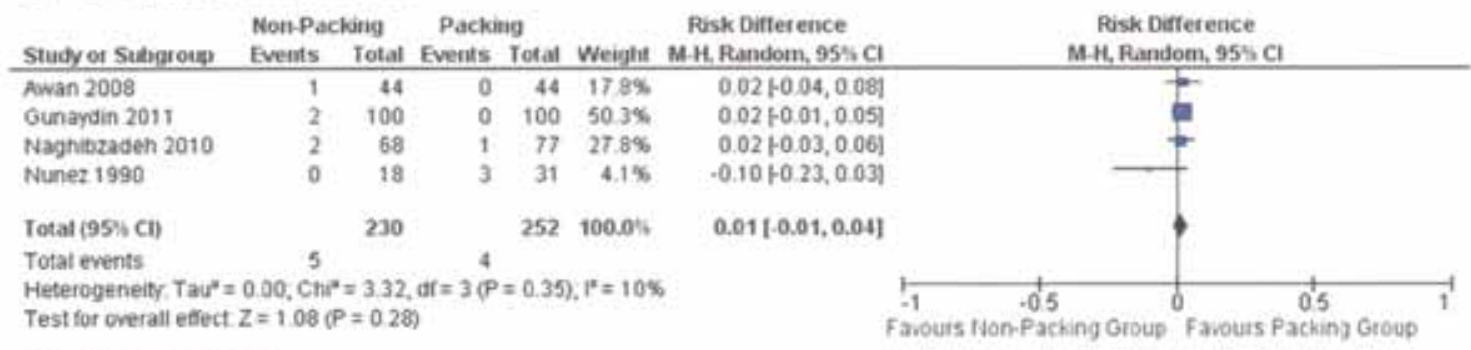

\section{c) Adhesions}

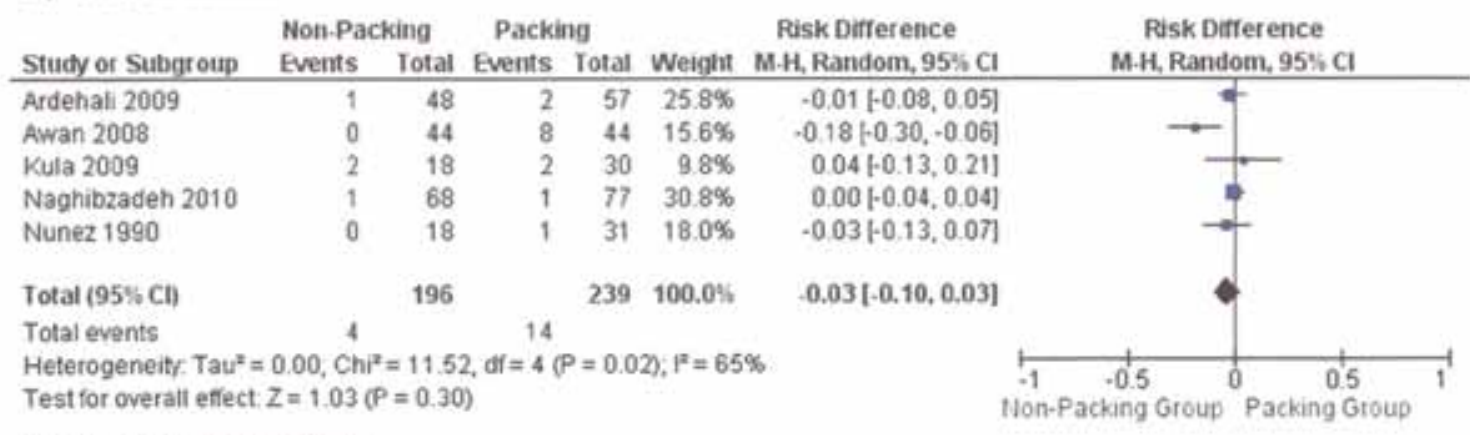

\section{d) Local infection}

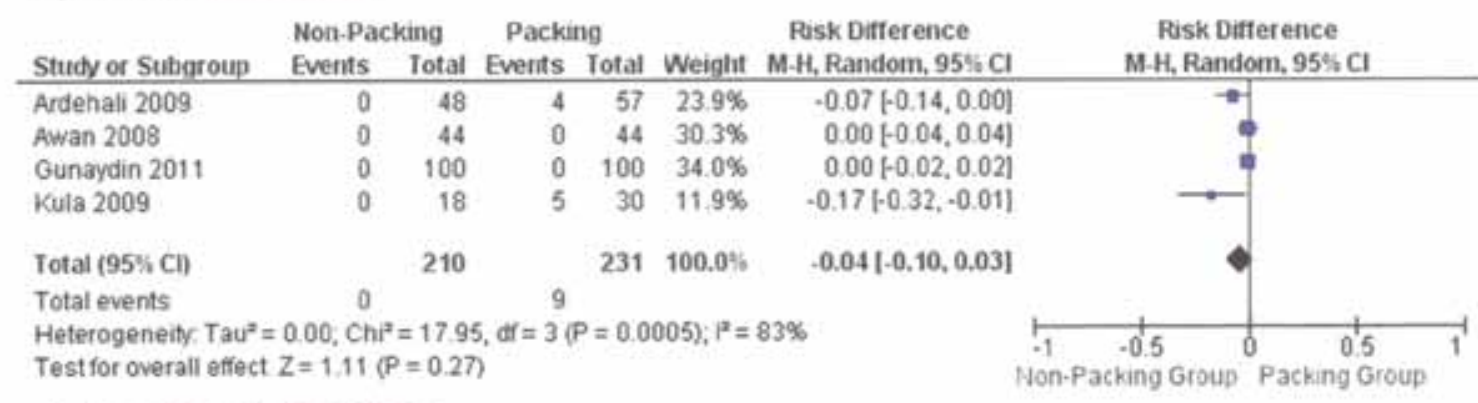

\section{e) Septal Perforation}

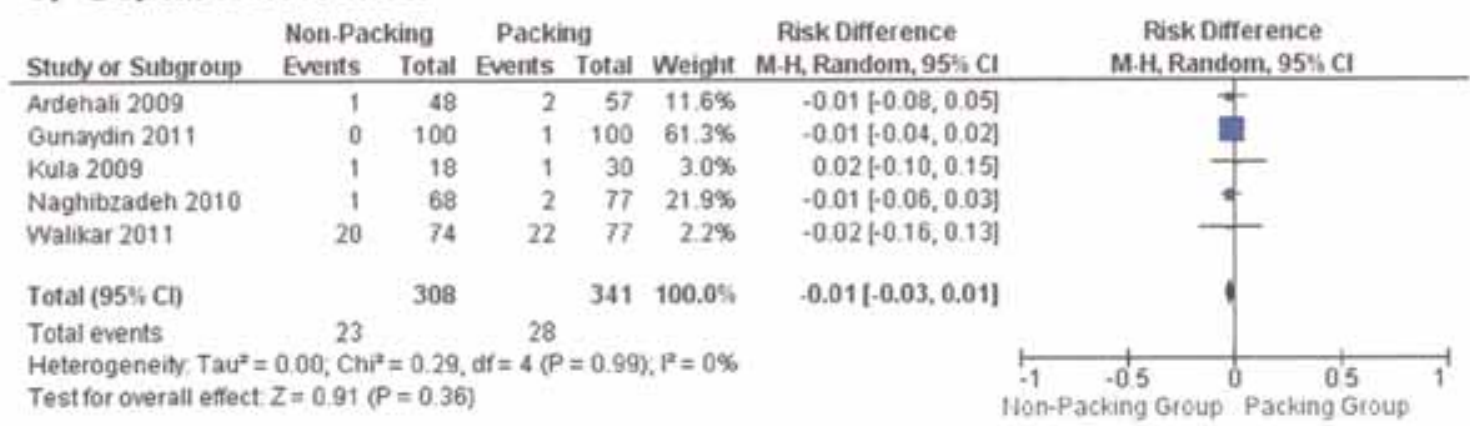

Figure 3. Results and pooled analysis of absolute risks differences for the secondary outcomes a) headache, b) septal haematoma, c) adhesions, d) local infection, e)septal perforation in trials comparing non-packing versus packing group in patients submitted to septoplasty. 


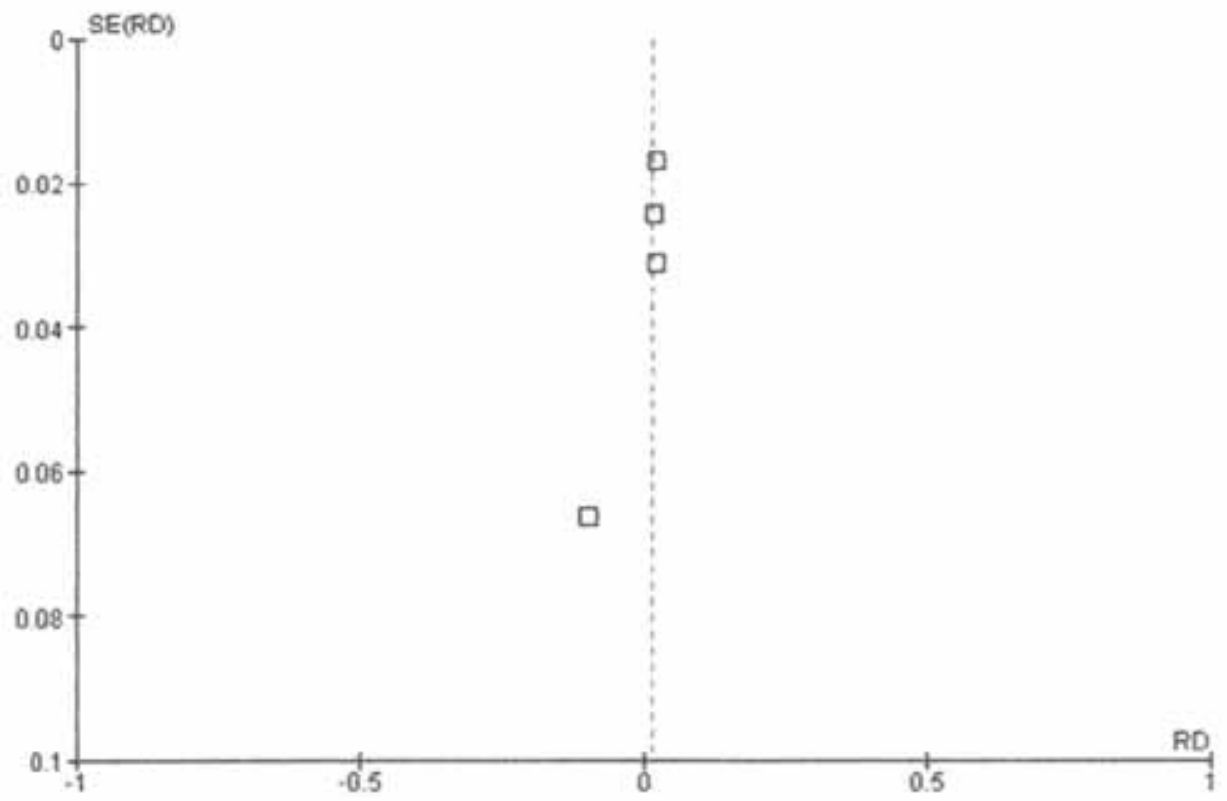

Figure 4. Funnel plot with effect measure (risk difference (RD)) as a function of its standard error (SE) for the outcome postoperative haemorrhage.

non-significant result ( $p=0.325$ ); therefore, the absence of publication bias cannot be rejected.

\section{Discussion}

Most surgeons still routinely use nasal packing after septoplasty. The reasons for packing include haemostasis, the prevention of septal haematoma, increased mucoperichondrial flap apposition, the closure of dead space, and the prevention of the displacement of replaced cartilage ${ }^{(22)}$. Nasal packing is not an innocuous procedure, and it may lead to several complications. The main disadvantage of packing is patient discomfort and the need for hospital stay ${ }^{(22)}$. Nasal packing has been reported as the leading cause of early postoperative pain ${ }^{(33)}$, and the removal of the packs is the most painful event in the postoperative period ${ }^{(2,4)}$.

Others complications have been related to pack insertion, including vasovagal attack, cardiovascular collapse, hypovolemic shock, and nasovagal reflex, as well as trauma to the columella, nasal mucosa, and soft palate ${ }^{(16)}$. Complications related to maintaining the pack include hypoxia and hypoxemia, which may lead to myocardial infarcts and cerebrovascular accidents, dysphagia, obstructive sleep apnea (OSA), vestibulitis or sinusitis, toxic shock syndrome, Eustachian tube obstruction/Toynbee phenomenon that may lead to otitis media with effusion, acute otitis media, and hemotympanum ${ }^{(16)}$. Late complications include adhesions, septal perforations, velopharyngeal incompetence or stenosis, and pack granuloma ${ }^{(16)}$.

In an attempt to overcome some of these drawbacks, Lee et al., (7) reported forms of continuous septal suturing in the $1980 \mathrm{~s}$.
A similar technique of septal suturing after nasal septoplasty without nasal packing was used in 226 consecutive surgical procedures and reviewed retrospectively by Lemmens et al., (10) who found that the septal suturing technique was a valid alternative to intranasal packing following septal surgery. However, there was no control group to support the results.

Several RCTs comparing suturing techniques and conventional packing have subsequently been published, and the role of this alternative is becoming more clearly defined. Gunaydin et al., ${ }^{25)}$ indicated that the arousal of the patient from anesthesia was easier and faster, and post-anesthesia follow-up durations and postoperative recovery times were shorter with the transseptal suturing technique.

The present meta-analysis focused on important, unresolved clinical questions on the efficacy and safety of this technique that could delaying its adoption by most centers.

First, the meta-analysis shows that in patients submitted to septoplasty without packing, the postoperative pain significantly decreases when compared with patients submitted to septoplasty with conventional postoperative packing. Packing and non-packing appear to be equivalent with regard to postoperative haemorrhage risk.

Second, our analysis of the secondary outcomes showed that although some caution is still necessary, there is no evidence for increased risk of adhesions, septal haematoma, septal perforation, or local infection in either of these groups. In contrast, our study found a higher risk of postoperative headache in the packing group. 


\begin{tabular}{|c|c|c|c|c|c|c|c|c|c|c|c|}
\hline 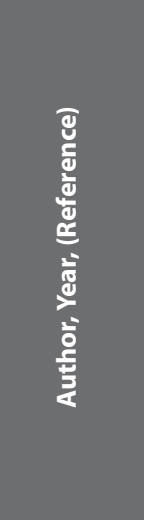 & है & $\begin{array}{l}\frac{N}{n} \\
\frac{0}{c} \\
\frac{\mathscr{E}}{\mathrm{n}}\end{array}$ & 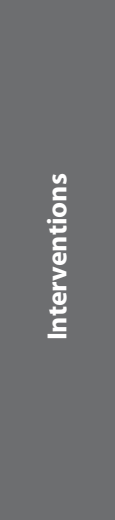 & ֻٓ & 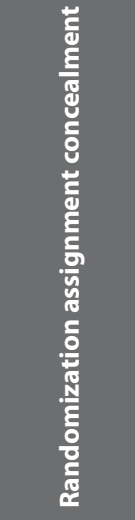 & 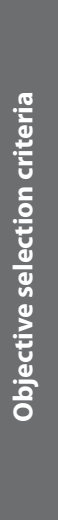 & ํㅡㄹ & 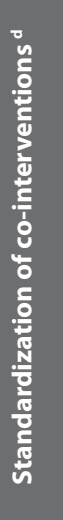 & 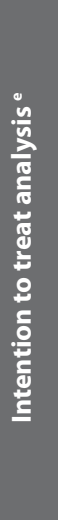 & 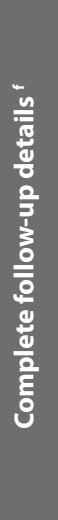 & 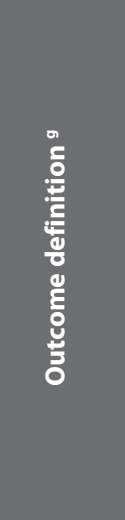 \\
\hline $\begin{array}{l}\text { Ardehali } \\
\text { et al., } \\
2009^{(26)}\end{array}$ & Iran & 114 & $\begin{array}{l}\text { Packing } \\
\text { vs. non- } \\
\text { packing }\end{array}$ & $\begin{array}{l}\text { Pain (VAS of } 1 \text { to 10); Postop- } \\
\text { erative septal haematoma; septal } \\
\text { perforation; residual deviation and } \\
\text { mucosal adhesion }\end{array}$ & Adequate & No & N.R. & Yes & No & Yes & Uncertain \\
\hline $\begin{array}{l}\text { Awan et al., } \\
2008^{(27)}\end{array}$ & Pakistan & 88 & $\begin{array}{l}\text { Packing } \\
\text { vs. non- } \\
\text { packing }\end{array}$ & $\begin{array}{l}\text { Pain (VAS of } 1 \text { to } 10 \text { ); Headache; } \\
\text { epiphora; dysphagia; sleep } \\
\text { disturbance; bleeding; septal } \\
\text { haematoma; adhesion formation } \\
\text { and infection }\end{array}$ & Adequate & Yes & N.R. & Yes & Yes & Yes & Uncertain \\
\hline $\begin{array}{l}\text { Günaydin } \\
\text { et al., } \\
2011^{(25)}\end{array}$ & Turkey & 200 & $\begin{array}{l}\text { Packing } \\
\text { vs. Non- } \\
\text { Packing }\end{array}$ & $\begin{array}{l}\text { Pain (VAS of } 1 \text { to 4); Bleeding; Sep- } \\
\text { tal Haematoma; Septal Perfora- } \\
\text { tion, Infection; Anaesthesiological } \\
\text { parameters }\end{array}$ & Uncertain & Yes & N.R. & Yes & Yes & Yes & Uncertain \\
\hline $\begin{array}{l}\text { Korkut et } \\
\text { al., } \\
2010^{(32)}\end{array}$ & Turkey & 64 & $\begin{array}{l}\text { Packing } \\
\text { vs. Non- } \\
\text { Packing }\end{array}$ & $\begin{array}{l}\text { Pain/discomfort; Headache; } \\
\text { Discomfort swallowing; Dry } \\
\text { mouth; Disturbed sleep; Increased } \\
\text { lacrimation }\end{array}$ & Uncertain & No & N.R. & Yes & Yes & Yes & Uncertain \\
\hline $\begin{array}{l}\text { Kula et al., } \\
2010(31)\end{array}$ & Turkey & 48 & $\begin{array}{l}\text { Packing } \\
\text { vs. Non- } \\
\text { Packing }\end{array}$ & $\begin{array}{l}\text { Mucociliary clearance function; } \\
\text { bleeding; Adhesion; septal perfo- } \\
\text { ration, Infection }\end{array}$ & Uncertain & Yes & N.R. & Yes & Yes & Yes & Uncertain \\
\hline $\begin{array}{l}\text { Naghibza- } \\
\text { deh et al., } \\
2011^{(28)}\end{array}$ & Iran & 145 & $\begin{array}{l}\text { Packing } \\
\text { vs. Non- } \\
\text { packing }\end{array}$ & $\begin{array}{l}\text { Pain; postoperative haemorrhage; } \\
\text { toxic shock syndrome; septal } \\
\text { haematoma; dangerous fungal } \\
\text { infection; septal deviation; septal } \\
\text { perforation; mucosal adhesions }\end{array}$ & Uncertain & Yes & N.R. & Yes & Yes & Yes & Uncertain \\
\hline $\begin{array}{l}\text { Nunez et } \\
\text { al., } \\
1991^{(3)}\end{array}$ & UK & 59 & $\begin{array}{l}\text { Packing } \\
\text { vs. Non- } \\
\text { packing }\end{array}$ & $\begin{array}{l}\text { Pain (VAS of } 1 \text { to } 10 \text { ); bleeding, } \\
\text { adhesions, crust, improvement in } \\
\text { nasal obstruction }\end{array}$ & Uncertain & No & N.R. & $\begin{array}{l}\text { Un- } \\
\text { cer- } \\
\text { tain }\end{array}$ & No & Yes & Uncertain \\
\hline $\begin{array}{l}\text { Walikar et } \\
\text { al., } \\
2011^{(30)}\end{array}$ & India & 151 & $\begin{array}{l}\text { Packing } \\
\text { vs. Non- } \\
\text { Packing }\end{array}$ & $\begin{array}{l}\text { Pain, headache, discomfort, septal } \\
\text { perforation }\end{array}$ & Uncertain & No & N.R. & $\begin{array}{l}\text { Un- } \\
\text { cer- } \\
\text { tain }\end{array}$ & No & No & Uncertain \\
\hline
\end{tabular}

Table 1. General characteristics and general quality criteria of randomized trials included in the study a Classified as: adequate, inadequate or uncertain. B Classified as: yes, if inclusion and exclusion criteria for participants are adequately reported; no, if selection criteria are not reported. C Classified as: yes, for articles that implemented blinding at any level; no, for articles reporting not being able to implement blinding of interventions at any level; not reported (NR), for articles that do not make any mention to blinding. D Classified as: yes, if there was an attempt to standardize treatment and care besides the assigned interventions; no, if no attempt to standardize was applied; uncertain, if it was not clearly reported. E Classified as: adequate; inadequate; uncertain. F Classified as: yes; no; not reported (NR). G Classified as: adequate if objective criteria for outcomes were defined; inadequate if the criteria were not defined; and uncertain if criteria application was uncertain (for example, depending on attending physician). N.R. = Not reported

Although our conclusions appear to be robust and well supported by the evidence, this meta-analysis has some limitations. We found important clinical differences among the studies included in the analysis. The patients selected may not be completely comparable among the studies. Specifically, we found relevant differences related to the inclusion and ex- 


\begin{tabular}{|c|c|c|c|c|c|c|}
\hline 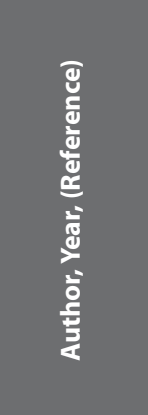 & 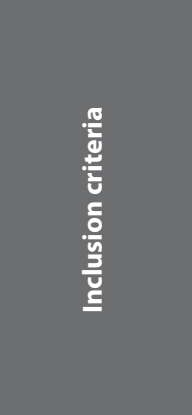 & 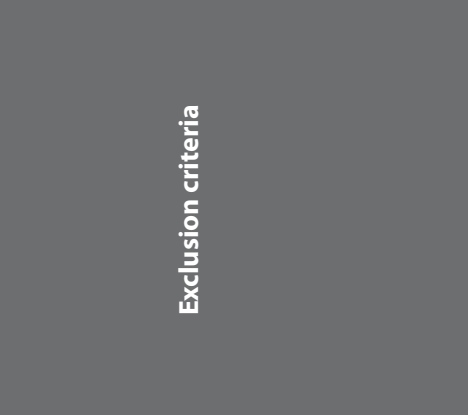 & 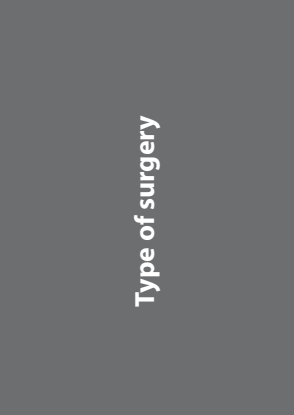 & 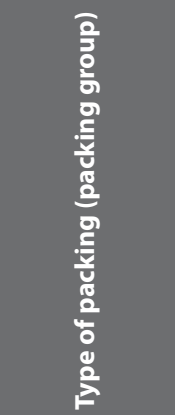 & 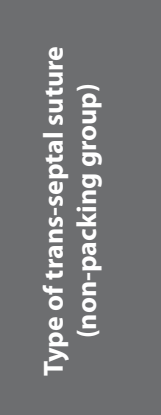 & 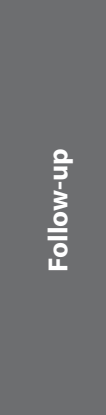 \\
\hline $\begin{array}{l}\text { Ardehali } \\
\text { et al., } \\
2009^{(26)}\end{array}$ & $\begin{array}{l}\text { Patients } \\
\text { with septal } \\
\text { deviation and } \\
\text { ensuing nasal } \\
\text { obstruction }\end{array}$ & $\begin{array}{l}\text { Patients who did not attend postop- } \\
\text { erative follow-up }\end{array}$ & $\begin{array}{l}\text { Septoplasty using the } \\
\text { submucosal approach } \\
\text { with hemitransfixion } \\
\text { incision }\end{array}$ & $\begin{array}{l}\text { tetracycline- } \\
\text { soaked mesh }\end{array}$ & $\begin{array}{l}\text { trans-septal } \\
\text { sutures }\end{array}$ & $\begin{array}{l}12 \\
\text { months }\end{array}$ \\
\hline $\begin{array}{l}\text { Awan et al., } \\
2008^{(27)}\end{array}$ & $\begin{array}{l}\text { Patients over } \\
15 \text { years old } \\
\text { admitted for } \\
\text { septal surgery }\end{array}$ & $\begin{array}{l}\text { History of cardiopulmonary disease, } \\
\text { diabetes, anticoagulation or bleeding } \\
\text { disorder, and revision surgery on the } \\
\text { nose }\end{array}$ & $\begin{array}{l}\text { Septoplasty using the } \\
\text { submucosal approach } \\
\text { with hemitransfixion } \\
\text { incision }\end{array}$ & $\begin{array}{l}\text { with glove } \\
\text { finger packs } \\
\text { lubricated } \\
\text { with petro- } \\
\text { leum-based } \\
\text { antibiotic } \\
\text { ointment }\end{array}$ & $\begin{array}{l}\text { septal } \\
\text { quilting } \\
\text { sutures }\end{array}$ & 7 days \\
\hline $\begin{array}{l}\text { Günaydin } \\
\text { et al., } \\
2011^{(25)}\end{array}$ & N.R. & $\begin{array}{l}\text { Turbinate or paranasal sinus pathology } \\
\text { or systemic disorders }\end{array}$ & $\begin{array}{l}\text { Septoplasty using the } \\
\text { submucosal approach } \\
\text { with hemitransfixion } \\
\text { incision }\end{array}$ & $\begin{array}{l}\text { Merocel }^{\circledR} \text { na- } \\
\text { sal dressing }\end{array}$ & $\begin{array}{l}2-4 \text { trans- } \\
\text { septal } \\
\text { sutures }\end{array}$ & $\begin{array}{l}5.25 \\
\text { months } \\
\text { (mean) }\end{array}$ \\
\hline $\begin{array}{l}\text { Korkut et } \\
\text { al., } \\
2010^{(32)}\end{array}$ & $\begin{array}{l}\text { Septal } \\
\text { deviation that } \\
\text { led to airway } \\
\text { obstruction }\end{array}$ & N.R. & $\begin{array}{l}\text { Septoplasty using the } \\
\text { submucosal approach } \\
\text { with hemitransfixion } \\
\text { incision }\end{array}$ & $\begin{array}{l}\text { preformed } \\
\text { tampon } \\
\text { Netcell }^{\circledR}\end{array}$ & $\begin{array}{l}\text { trans-septal } \\
\text { sutures }\end{array}$ & $\begin{array}{l}3 \\
\text { months }\end{array}$ \\
\hline $\begin{array}{l}\text { Kula et al., } \\
2010^{(31)}\end{array}$ & $\begin{array}{l}\text { Symptomatic } \\
\text { nasal septal } \\
\text { deviation } \\
\text { diagnosed by } \\
\text { endoscopy } \\
\text { and acoustic } \\
\text { rhinometry }\end{array}$ & $\begin{array}{l}\text { Nasal polyp, diabetes mellitus, allergic } \\
\text { rhinitis and history of nasal surgery }\end{array}$ & $\begin{array}{l}\text { Septoplasty using the } \\
\text { submucosal approach } \\
\text { with hemitransfixion } \\
\text { incision }\end{array}$ & $\begin{array}{l}\text { Group 1: fin- } \\
\text { gerstall filled } \\
\text { with gauze } \\
\text { and smeared } \\
\text { with Vase- } \\
\text { line. Group 2: } \\
\text { Silicon septal } \\
\text { splint packs }\end{array}$ & $\begin{array}{l}\text { hemostatic } \\
\text { septal } \\
\text { sutures }\end{array}$ & N.R. \\
\hline $\begin{array}{l}\text { Naghibza- } \\
\text { deh et al., } \\
2011^{(28)}\end{array}$ & N.R. & $\begin{array}{l}\text { Patients more than } 65 \text { years old, } \\
\text { patients suffering from diabetes, heart } \\
\text { problems, hypertension, any kind of } \\
\text { vasculitis, blood dyscrasia, history of } \\
\text { nasal polyposis, drug abuse, history of } \\
\text { overt nasal allergy, using hemodiluting } \\
\text { drugs like aspirin, and patients with } \\
\text { a history of previous septal and nasal } \\
\text { turbinate surgery }\end{array}$ & $\begin{array}{l}\text { Septoplasty using the } \\
\text { submucosal approach } \\
\text { with hemitransfixion } \\
\text { incision in } 138 \text { cases. } \\
\text { Septoplasty by external } \\
\text { approach in } 7 \text { cases. }\end{array}$ & $\begin{array}{l}\text { with } \\
\text { tetracycline- } \\
\text { impregnated } \\
\text { gauze }\end{array}$ & $\begin{array}{l}\text { trans-septal } \\
\text { sutures }\end{array}$ & $\begin{array}{l}\text { 3-32 } \\
\text { months }\end{array}$ \\
\hline $\begin{array}{l}\text { Nunez et } \\
\text { al., } 1991^{(3)}\end{array}$ & $\begin{array}{l}\text { Patients over } \\
18 \text { years old } \\
\text { admitted for } \\
\text { septal surgery }\end{array}$ & N.R. & $\begin{array}{l}\text { Septoplasty using the } \\
\text { submucosal approach } \\
\text { with hemitransfixion } \\
\text { incision }\end{array}$ & $\begin{array}{l}\text { with Vaseline } \\
\text { gauze pack- } \\
\text { ing }\end{array}$ & $\begin{array}{l}30 \text { Dexon } \\
\text { quilt suture } \\
\text { of the } \\
\text { septum }\end{array}$ & 6 weeks \\
\hline $\begin{array}{l}\text { Walikar et } \\
\text { al., } 2011^{(30)}\end{array}$ & $\begin{array}{l}\text { Anterior } \\
\text { deviated nasal } \\
\text { septum }\end{array}$ & $\begin{array}{l}\text { Posterior deviation of nasal septum, } \\
\text { midfacial anomalies and patients with } \\
\text { HIV }\end{array}$ & $\begin{array}{l}\text { Septoplasty using the } \\
\text { submucosal approach } \\
\text { with hemitransfixion } \\
\text { incision }\end{array}$ & N.R. & $\begin{array}{l}\text { Trans-septal } \\
\text { sutures }\end{array}$ & N.R. \\
\hline
\end{tabular}

Table 2. Specific characteristics of randomized trials included in the study.

N.R. $=$ Not reported 


\begin{tabular}{|c|c|c|c|}
\hline & & \multirow{2}{*}{\multicolumn{2}{|c|}{ Results }} \\
\hline & & & \\
\hline Author, Year, (Reference) & Pain evaluation & Packing group & Non-Packing group \\
\hline Ardehali et al., $2009^{(26)}$ & $\begin{array}{l}\text { Pain evaluated on the first postop- } \\
\text { erative day, through VAS of } 1 \text { to } 10\end{array}$ & 5 & 2.1 \\
\hline Awan et al., $2008^{(27)}$ & $\begin{array}{l}\text { Pain evaluated on the first postop- } \\
\text { erative day, through VAS of } 1 \text { to } 10\end{array}$ & 7.32 & 1.57 \\
\hline Günaydin et al., $2011^{(25)}$ & $\begin{array}{l}\text { Pain evaluated on the first postop- } \\
\text { erative day, through VAS of } 1 \text { to } 4\end{array}$ & 2.36 & 0.95 \\
\hline Korkut et al., $2010^{(32)}$ & N.R. & \multicolumn{2}{|c|}{$\begin{array}{l}\text { "Significantly less in the group with trans-septal suturing } \\
\text { compared to the group with nasal packing" }\end{array}$} \\
\hline Kula et al., $2010^{(31)}$ & N.R. & \multicolumn{2}{|c|}{ "pain was more common with nasal packing" } \\
\hline Naghibzadeh et al., $2011^{(28)}$ & $\begin{array}{l}\text { Pain evaluated through number of } \\
\text { patients suffering of severe pain } \\
\text { feeling }\end{array}$ & $77 / 77$ & $2 / 68$ \\
\hline Nunez et al., $1991^{(3)}$ & $\begin{array}{l}\text { Pain evaluated on the first postop- } \\
\text { erative day, through VAS of } 1 \text { to } 10\end{array}$ & 4.11 & 2.92 \\
\hline Walikar et al., $2011^{(30)}$ & $\begin{array}{l}\text { Pain evaluated through number of } \\
\text { patients suffering of postoperative } \\
\text { pain/discomfort }\end{array}$ & $61 / 77$ & $19 / 74$ \\
\hline
\end{tabular}

Table 3. Results of postoperative pain/discomfort among included studies.

N.R. $=$ Not reported

clusion criteria. For instance, Naghibzadeh et al., ${ }^{(28)}$ described extensive exclusion criteria but did not include any information on the inclusion criteria; in contrast, Nunez et al., ${ }^{(28)}$ and Korkut et al., ${ }^{(32)}$ did not describe any exclusion factors. However, the differences related to recruitment among the studies included in this meta-analysis do not seem to account for the differences in the results.

Some of the studies included had severe methodological limitations. When analysing the comparison between the packing and non-packing group, some concern may be raised about the randomization procedures. In fact, only 2 studies ${ }^{(26,27)}$ described the randomization that was performed. The remaining studies did not provide any information on the randomization process, and none of the studies reported or commented on blinding strategies.

Important heterogeneity was also found in relation to the outcome definitions. For example, the criteria and time frame used in the definition of postoperative pain varied among the studies. Moreover, some studies did not provide any criteria for the measurement of such outcomes. Similarly, none of the studies study clearly described how to define the remaining outcomes; it is therefore unclear whether substantial variation was present among the studies regarding the explicit criteria for the definition of these outcomes. However, substantial variation in the implicit threshold could be expected among the studies, as the test results (presence or absence of outcomes) depend on the perceptions, interpretation, and judgment of the observers. The creation of consensus guidelines for outcome definitions for this type of study would be useful to promote further rigorous research and would support future systematic reviewers.

Minor differences were also found in the technical specifications of the suturing technique. Although horizontal transseptal sutures were the main technique used in some studies, variations of this technique were used in other studies. Seven septoplasties were performed by external approach for septorhinoplasty, but no difference in the outcomes was described by the authors ${ }^{(28)}$. However, it seems unlikely that these technical adjustments had a major impact on the outcomes.

Finally, a search for a potential publication bias was performed using funnel plots and the rank correlation test of Begg. Using these methods, it is not possible to rule out the possibility of publication bias in our meta-analysis. We found some evidence to indicate that smaller studies are more likely to be published if they have larger effects and some evidence of a publication bias favoring the publication of studies with positive results for non-packing when compared with conventional packing. However, we should consider that the rank correlation test of Begg has a low power. It is also important to emphasize that the asymmetry found in funnel plots could be related to several other sources of bias and is not necessarily evidence of publication bias.

\section{Conclusion}

The evidence for the advantage of suturing techniques over conventional packing in septoplasty is now robust, and the use 
of suturing techniques as a first line intervention is becoming advisable. Although the consensus in current world literature is that packing should be avoided, non-packing alternatives such as postoperative suturing techniques are still underused in many ENT centers, partly because the clinical questions that we address in this meta-analysis had not been answered. Suturing technique and conventional packing showed similar risk for postoperative haemorrhage, septal perforation, septal haematoma, mucosal adhesions, and local infection. However, suturing indicated a significant decrease in the postoperative pain and headache; therefore, it can be considered as the preferred packing intervention in septoplasty.

Finally, we consider that it is important for researchers in this field to create consensus guidelines for methods of reporting and defining populations, interventions, and outcome measures. The evidence presented here suggests that further research should be performed to compare suturing methods with conventional packing in septoplasty, using a robust methodological approach to create RCTs with higher quality. Research in the future should also concentrate on the definition of subgroups of patients for whom conventional packing could eventually be advantageous over suturing.

\section{Financial disclosure and conflict of interest} None

\section{References}

1. Dubin MR, Pletcher SD. Postoperative Packing After Septoplasty: Is It Necessary? Otolaryngol Clin North Am. 2009; 42: 279285.

2. von Schoenberg M, Robinson P, Ryan R. Nasal packing after routine nasal surgery-is it justified? J Laryngol Otol. 1993; 107 902-905.

3. Nunez DA, Martin FW. An evaluation of post-operative packing in nasal septal surgery. Clin Otolaryngol Allied Sci. 1991; 16 549-550.

4. Samad I, Stevens HE, Maloney A. The efficacy of nasal septal surgery. J Otolaryngol. 1992; 21: 88-91

5. Taasan V, Wynne JW, Block AJ. The effect of nasal packing on sleep-disordered breathing and nocturnal oxygen desaturation. Laryngoscope. 1981; 91: 1163-1172.

6. Sessions RB. Membrane approximation by continuous mattress sutures following septoplasty. Laryngoscope. 1984; 94: 702-703.

7. Lee IN, Vukovic L. Hemostatic suture for septoplasty: How we do it. J Otolaryngol. 1988; 17: 54-56.

8. Hari C, Marnane C, Wormald PJ. Quilting sutures for nasal septum. J Laryngol Otol. 2008; 122: 522-523.

9. Moher D, Cook DJ, Eastwood S, et al. Improving the quality of reports of metaanalyses of randomised controlled trials: the QUOROM statement. Quality of Reporting of Meta-analyses. Lancet. 1999; 354: 18961900.

10. Schechtman $\mathrm{E}$, Odds ratio, relative risk, absolute risk reduction, and the number needed to treat--which of these should we use? Value Health. 2002; 5: 431-436.

11. Walter SD. Choice of effect measure for epidemiological data. J Clin Epidemiol. 2000; 53: 931-939.

12. Begg CB, Mazumdar M. Operating characteristics of a rank correlation test for publication bias. Biometrics. 1994; 50: 1088-1101.

13. Vaiman M, Eviatar E, Segal S. The use of fibrin glue as hemostatic in endonasal operations: A prospective, randomized study. Rhinology. 2002; 40: 185-188.

14. Vaiman M, Sarfaty S, Shlamkovich N, Eviatar E. Fibrin sealant: Alternative to nasal pack- ing in endonasal operations. A prospective randomized study. Isr Med Assoc J. 2005; 7 : 571-574.

15. Kazkayasi M, Dinçer C, Sezikli H, Arikan OK, Caglayan $\mathrm{O}$. The effect of suturing technique and nasal packing on oxidative stress in septoplasty operations. Kulak Burun Bogaz Ihtis Derg. 2008; 18: 35-39.

16. Veluswamy A, Handa S, Shivaswamy S. Nasal Septal Clips: An Alternative to Nasal Packing After Septal Surgery? Ind J Otolaryngol and Head and Neck Surgery. 2011; 1-5.

17. Manzini M, Cuda D, Caroggio A. Nasal packing and antibiotic prophylaxis in septoplasty: a controlled study. Acta Otorhinolaryngol Ital. 1998; 18: 88-95.

18. Juan $\mathrm{KH}$. Suture technique to correct caudal septal deviations. Gaoxiong Yi Xue Ke Xue Za Zhi. 1995; 11: 448-452.

19. Calderón-Cuéllar LT, Trujilio-Hernández, Vásquez C, Padilla-Acero J. Modified mattress suture technique to correct anterior septal deviation. Plast Reconstr Surg. 2004; 114: 1436-1441.

20. Wullstein SR. Septoplasty without postoperative nasal packing. Mucosal repair of the upper airway with human biologic glue. Die septumplastik bzw. submukose septumresektion ohne postoperative nasentamponade. schonung der schleimhaute der oberen luftwege durch die anwendung des humanbiologischen gewebeklebers HNO. 1979; 27: 322-324.

21. Malki D, Quine SM, Pfleiderer AG. Nasal splints, revisited. J Laryngol Otol. 1999; 113: 725-727.

22. Lemmens $W$, Lemkens P. Septal suturing following nasal septoplasty, a valid alternative for nasal packing? Acta Otorhinolaryngol Belg. 2001; 55: 215-221

23. Reiter D, Alford E, Jabourian Z. Alternatives to packing in septorhinoplasty. Arch Otolaryngol Head Neck Surg. 1989; 115: 1203-1205.

24. Bajaj Y, Kanatas AN, Carr S, Sethi N, Kelly G. Is nasal packing really required after septoplasty? IJCP. 2009; 63: 757-759

25. Günaydin RÖ, Aygenc E, Karakullukcu S, Fidan F, Celkkanat S. Nasal packing and transseptal suturing techniques: Surgical and anaesthetic perspectives. Eur Arch of
Otorhinolaryngol. 2011; 268: 1151-1156.

26. Ardehali MM, Bastaninejad S. Use of nasal packs and intranasal septal splints following septoplasty. Int J of Oral Maxillofac Surg. 2009; 38: 1022-1024.

27. Awan MS, lqbal M. Nasal packing after septoplasty: a randomized comparison of packing versus no packing in 88 patients. Ear Nose Throat J. 2008; 87: 624-627.

28. Naghibzadeh B, Peyvandi AA, Naghibzadeh G. Does post septoplasty nasal packing reduce complications? Acta Medica Iranica. 2011; 49: 9-12.

29. Korkut AY, Erkalp K, Erden V, et al. A Effect of pharyngeal packing during nasal surgery on postoperative nausea and vomiting. Otolaryngol Head Neck Surg. 2010; 143: 831-836.

30. Walikar, BN, et al., A Comparative Study of Septoplasty With or Without Nasal Packing. In J Otolaryngol Head Neck Surg, 2011; 63: 247-248.

31. Kula M, Yuce Y, Tutus A, Cagli S, Ketenci L. Effect of nasal packing and haemostatic septal suture on mucociliary activity after septoplasty: An assessment by rhinoscintigraphy. Eur Arch Otorhinolaryngol. 2010; 267: 541-546.

32. Korkut AY, Teker AM, Eren SB, Gedekli O, Askiner $O$. A randomised prospective trial of trans-septal suturing using a novel device versus nasal packing for septoplasty. Rhinology. 2010; 48: 179-182.

33. Yilmazer C, Sener M, Yilmaz I, et al. Preemptive analgesia for removal of nasal packing: A double-blind placebo controlled study. Auris Nasus Larynx. 2007; 34: 471-475.

\section{Victor Certal}

Rua Dr. Cândido de Pinho

4520-211 Santa Maria da Feira

Portugal

Tel: (+351) 966839235

E-mail: victorcertal@gmail.com 